\title{
To Vote or Not to Vote: A Study of Political Psychology on the Millennial Generation towards 2019 General Election
}

\author{
Abdul Azis ${ }^{1}$ \\ \{abdulazis@mail.unnes.ac.id ${ }^{1}$ \} \\ Universitas Negeri Semarang, Indonesia ${ }^{1}$
}

\begin{abstract}
This research investigates the attitude of the millennials on the current General Election demonstrated by their willingness to vote or not to vote, and why. The population of this study is the millennial generation who is eligible to vote, in this case university students. 118 random samples were taken randomly. An attitude scale is designed for the purpose of this research to measure the attitude and tendency of the students. The data is then analysed descriptively by employing political psychology as a conceptual lens to theorise the attitude. The findings reveal that positive perception of the Election helps students to act positively by using their vote, while negative perception renders them apathetic on the political process.
\end{abstract}

Keywords: Vote, Political Psychology, Attitude, Perception, Millennial Generation.

\section{Introduction}

Millennial generation has been recently under the highlight, especially during the recent General Election 2019. They have been widely discussed regarding their political perspectives and attitudes. This is reasonable because according to a political observer Voxpop Center Pangi $\mathrm{S}$ Chaniago the aggregrate numbers of voters coming from this layer of generation reaches up to $40 \%$. Saiful Mujani Research \& Consulting (SMRC) also shares similar survey results that in 2019 the millennial generation or voters within the range of $17-38$ years are up to $55 \%$. Given this wide share, there are many political parties paying special attention to the millennial generation while designing their political strategies.

In addition, the circulating stereotypes around the millennials is that they are indifferent to any political processes. In relation to this, the survey conducted by the Center for Strategic and International Studies (CSIS) and the Research and Development of Kompas confirms this political apathetism. In November 2018, the CSIS survey that reveals the relationship between the millennials and their interests in social-political issues demonstrate only $2.3 \%$ who shows interests. The Research and Development of Kompas also shows only $11 \%$ of them who wants to participate directly in practical politics or being involved in political parties. These two surveys show that political issue is one issue the millennials do not like. However, there is not any research that specifically discusses the relationship between the millennials and their political attitudes in the General Election and voting tendency.

This research aims to investigate the attitude of the millennials on the current General Election demonstrated by their willingness to vote or not to vote from a psychological 
perspective. In discussing the individual behaviours and its relation to political worlds, a psychological perspective is needed to explain why a person is more interested in the political process or not, and why they vote or not. Political psychology is a multidisciplinary field that embraces psychology and politics in order to understand the individual political behavior and processes which are based on cognitive and social tendencies. In other words, the study of political psychology attempts to explore how psychological patterns affect the way individuals behave in politics. Each individual person behaves according to their characteristics, personality, values, and affinity in group that we can draw a bigger pattern from.

To achieve the goal, the structure of this writing is organized as follows. Firstly, it starts with studying the characteristics of the millennials, especially their political attitude and behaviors from the literature. Secondly, this writing explains the method used in the researching processes from data collection technique, data analysis technique, and its approaches. Thirdly, the core of this writing is discussing the relationship between the millennials and their political attitude in the general election with the main question: to vote or not to vote?

\section{Political Psychology}

Attitude is an evaluation or reaction of feeling. According to Louis Thurstone et al [1], this evaluation takes forms favoring or not favoring on certain objects or subjects. Ahmadi [2] defines attitude as something that determines characters, essesence, either the current behavior or in the future.

Political attitude, according to Sastroadmodjo [3], is individual readiness to react on certain objects that are political in nature, as living with the related objects. While Plano [4] defines political attitude as an intersection amongst embedded values that drives someone to respond to a political situation or object in a certain way.

Political attitude is strongly related to political socialization. According to Rush and Phillip Althoff [5], political socialization is a process of introducing a political system to someone, and how it defines responses and their reactions on political symptoms.

There are some factors that influence individual or societal attitudes on political system or political object, Almond and Sidney Verba [6] mention three components of political attitude. They are cognitive, affective, and evaluative components. Cognitive component deals with knowledge about politics and beliefs on polirtics, its roles and obligations as well as its inputs and output. The cognitive component has three layers of knowledge about political system, political elites, policies, or symbols owned by the political system. Secondly, affective component deals with feeling and emotion of every citizen. Every individual has specific emotional tendencies to certain political aspects that drives them accept or reject certain systems. Thirdly, evaluative component means decision or opinion on political objects that are typically involved the combination of standards and criteria of certain values with information and feelings. This evaluative component is determined by moral orientation.

The millennials are considered as voters. According to Law Number 1-year 2015, voters are citizens who are minimally 17 years old or are/have been married by the time of the election. Looking at the age range, the millennials are eligible voters according to the Law.

Who are these millennial generation actually? The term comes from the millennials coined by William Strauss and Neil Howe [7] in their book. In some other books, they are called generation me or echo boomers. The terms have been adopted and used by politicians in designing their political strategies. According to social researchers, generation $\mathrm{Y}$ or the 
millennials are born in between 1980s to 2000s. In other words, the millennials are the young people around 15-35 years old.

The millennials have certain characteristics because they are born in the time when television has already been colorful and is controlled by a remote control. Besides, they know and even use mobile phones from schooling age with internet as its main supporting needs. The elder generation from the millennials label them with laziness and narcissism.

But, are they interested in political processes and issues? The millennials are judged to be apathetic to social issues. They are also thought to be indifferent to political and economic development and become abstain voters. Another stereotype is that they tend to leave cultural and religious values behind and chasing hedonism.

That is merely stereotypes. The ones labelled by elder generations on the millennials. Therefore, it needs a research that closely discusses the attitude of the millennials. The data of the 2019 general election is completely different from the previous elections because they compose half of voters and thus most political parties' approach and target them.

\section{Research Method}

This is a descriptive qualitative research to understand the political attitude of the millennials. The population is university freshmen who are eligible to vote. The sample was 118 students and they were randomly chosen. Sampling technique

Data were collected through distributing online questionnaire (via google forms) on the targeted sampling. 118 students from three universities in Central Java were managed to fill out the questionnaire. The three universities come from different institutional clusters: they are a first cluster public university, a second cluster public university, and a third cluster private university.

The survey was based on Likert scale to measure individual attitude, opinion, and perception on the 2019 election process. The answer of each item has gradation from very positive or strongly agree to very negative or strongly disagree (1-5 scale). The survey was conducted for two days during the silent days before the election, that was 15 and 16 April 2019 (the election day was on 17 April 2019). The data analysis used to understand the attitude was descriptive statistics.

\section{Research Findings}

The points presented and discussed in this section is not the overall survey, but only some relevant parts to the objective of this paper. The relevant points are respondents' identities, the use of vote, understanding on the procedure of election, knowing the official list of voters, knowing the time and location of voting, understanding the vision and mission of the candidates, and the views of political parties.

\subsection{Respondents' Identities}


The respondents in this research are students of three universities in Central Java who are eligible to vote. The identity of the respondents according to their age can be seen in the following chart:

$59 / 118$ correct responses

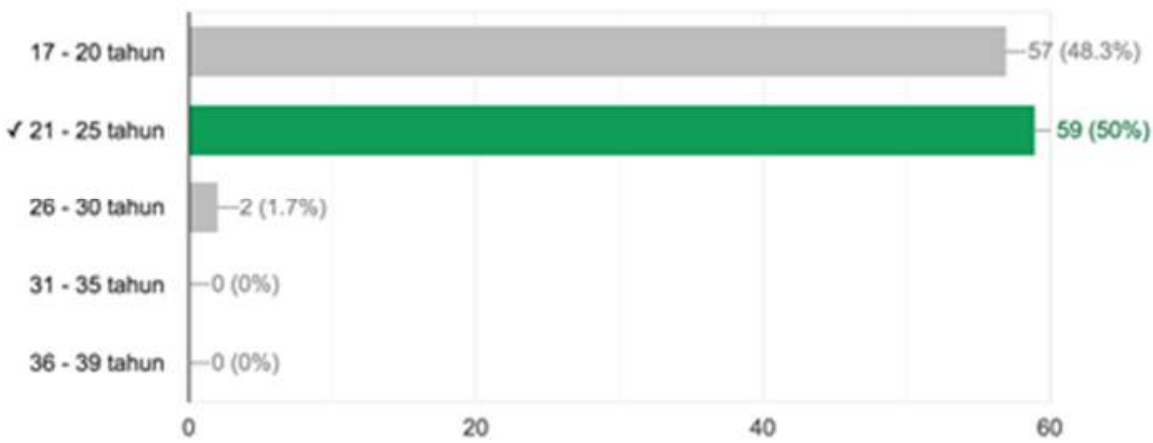

Figure 1. Age group of respondents.

According to the above chart, all respondents who participated in the survey can be categorized into millennial generation who belong to $21-25$ age group are 50 percent, while those under the 17-20 age group category account for 48.3 percent and 26-30 years old for 1.7 percent.

\subsubsection{To Vote or Not to Vote?}

The survey demonstrates that 69.5 percent are interested and excited to vote in 2019. While 17.8 percent are interested, and 7.6 percent are so-so. Only 5.1 percent who are somewhat interested. The following is the chart of the use of vote.

\footnotetext{
118 responses
}

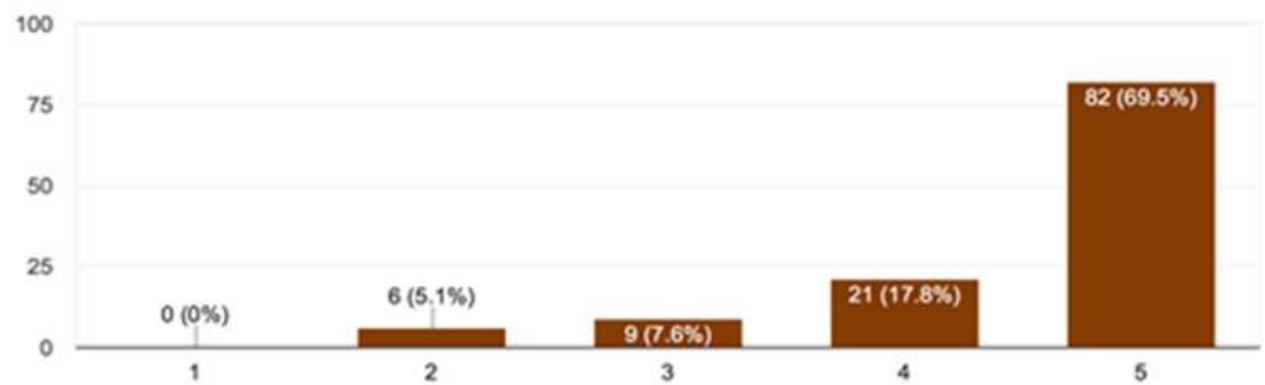

Figure 2. The use of vote. 
The above chart shows that the millennial generation is actually interested in the election process and would like to participate in the 2019 election. This finding contradicts with the previous studies and stereotypes that the millennials are indifferent with the political processes.

\subsubsection{Understanding on the Procedures of Election}

The millennials' interest is supported by their understanding on the procedures of the election process. The survey reveals that 48.3 percent of respondents understand so well, 37.3 percent understand and know how to vote, and 12.7 percent are neutral or so-so and 1.7 percent do not understand or do not know the election/voting procedures.

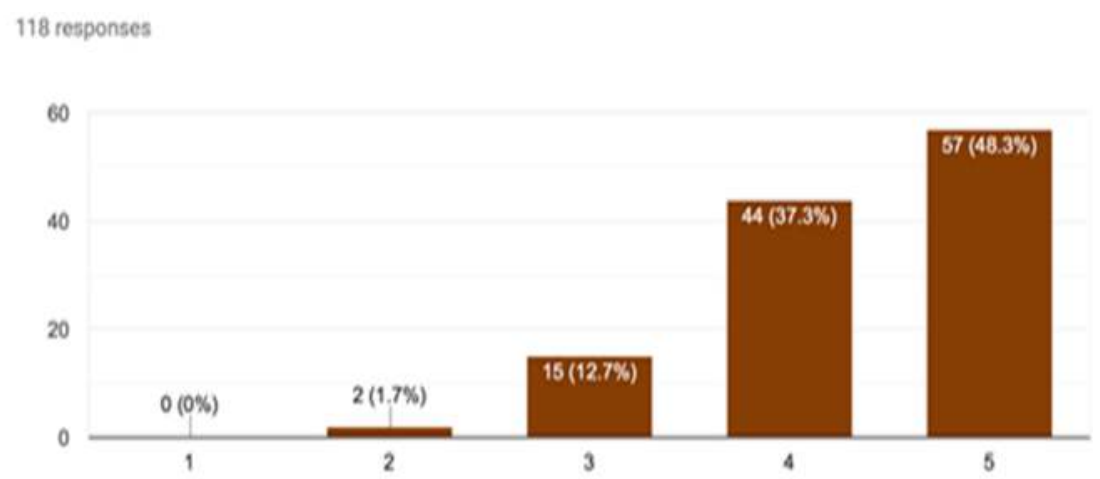

Figure 3. Understand how to vote.

The above chart and explanation show that the millennials understand the 2019 election procedures so well. This counters the assumption that millennials are lazy and reluctant to learn and understand the political processes of election

\subsubsection{Knowing the Official List of Voters}

Other than being interested and understand of the election procedures, the millennials know and are aware of the fact that they are enrolled in the official list of voters. The majority of the respondents (75.4 percent) know so well that they are enrolled. 16.1 know that they are enrolled, 5.9 percent are neutral, 0.8 percent do not know and only 1.7 percent do not know anything. 


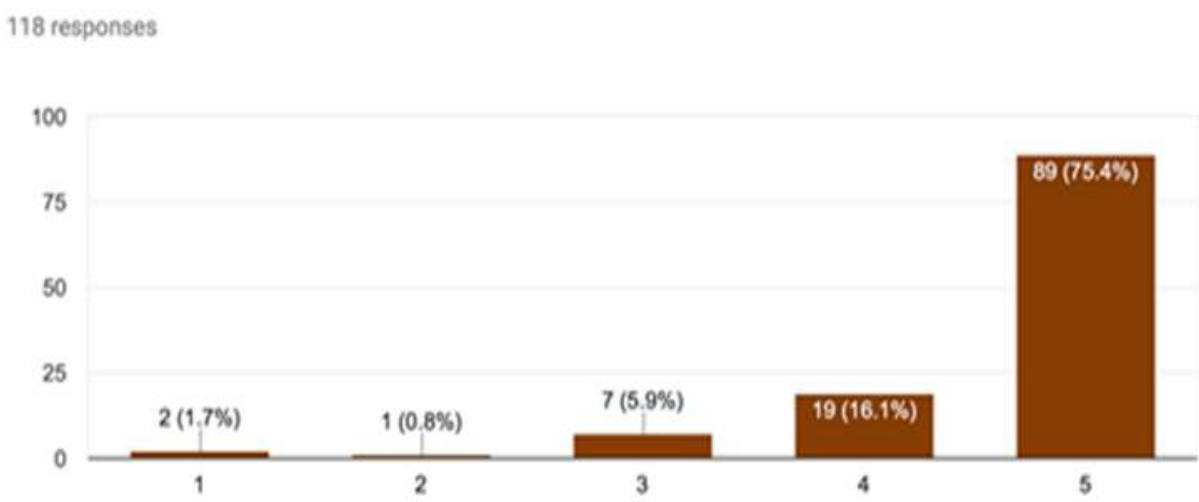

Figure 4. knowing the official list of voters.

The above chart depicts that the millennials are aware and knowledgeable about the procedures of how to be officially registered as eligible voters. This negates the taken for granted assumption that they are apathetic of political processes.

\subsubsection{Knowing the Time and Location of Voting}

The survey also shows that the majority of our respondents ( 72 percent) are well aware and knowledgeable about the time and location of voting. 21.2 percent are aware, while 5 percent are neutral and only 1.7 percent do not know the voting location and time.

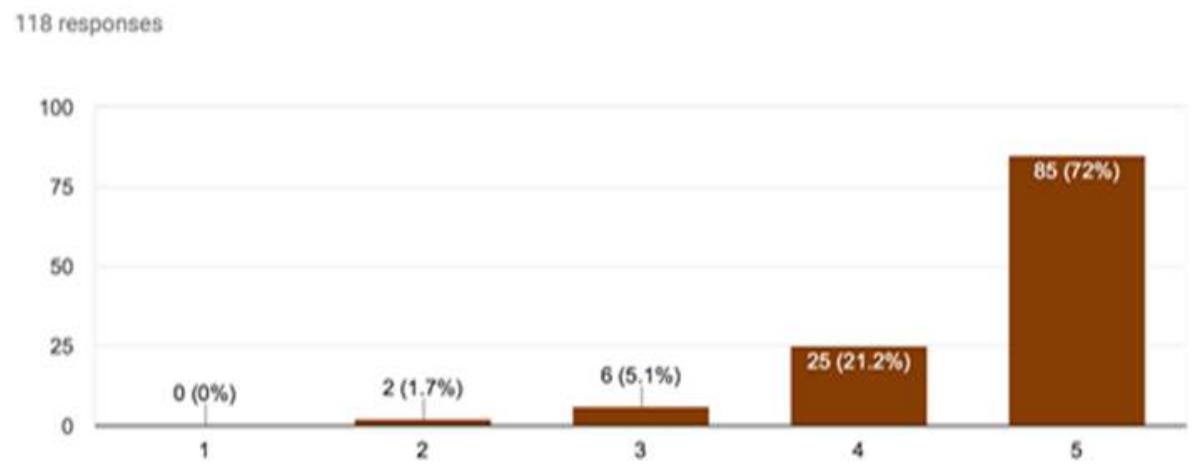

Figure 5. knowing the time and location of voting.

The above figure demonstrates the readiness of the millennials to vote, that they have a valid basic information of where and when to vote. This point also negates the taken for granted assumption about the millennials.

\subsubsection{Feeling to Vote}

This section demonstrates the millennials' feeling on the political processes, especially given the fact that they are now eligible voters. This is to measure their excitement over the 
euphoria of election. Almost a half of the respondents (49.2 percent) are very excited in the election process. While 26.3 percent are just excited, and 21.2 percent have neutral feeling, and 3.4 percent are not excited.

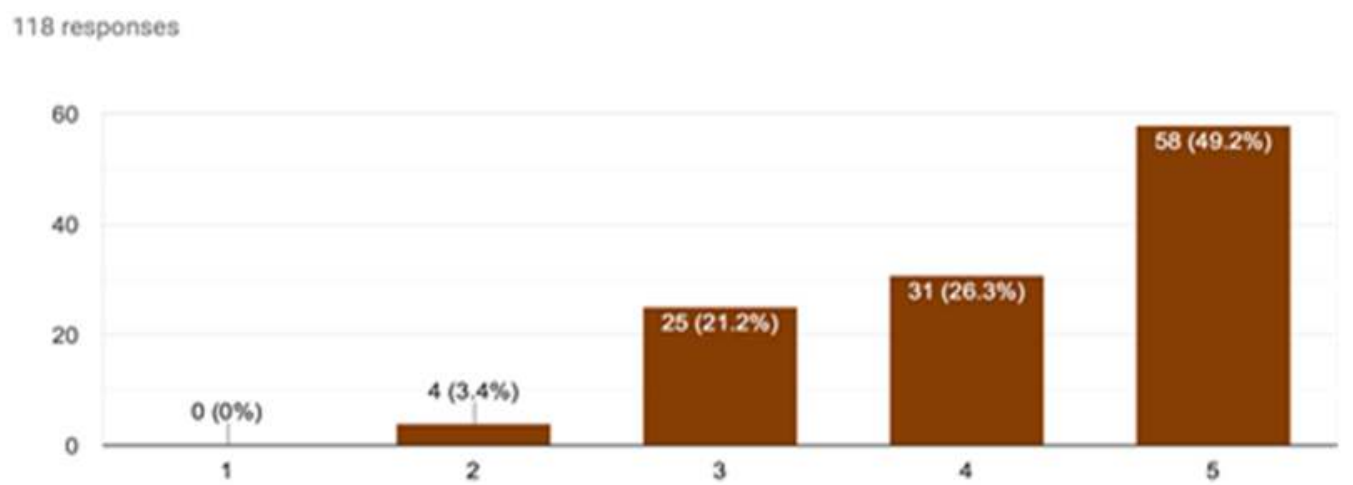

Figure 6. Excited to vote.

The above figure shows a considerably high level of excitement as the majority of the respondents are very excited and just excited. This might be because this year's election is the first election they experience.

\subsubsection{Understanding the Vision, Mission and Views of Political Parties}

It is surprising, as our survey reveals, that the millennials also understand the vision, mission and views of political parties that propose candidates. An aggregate of 35.6 percent (the combined shares of 19.5 percent who knows and 16.1 percent who knows very well) and 33.9 percent (the combined shares of 22.9 percent of those who do not know and 11 percent who knows nothing at all) and 30.5 percent who are neutral. The statistics shows an even distribution of those who understand, neutral and do not. This pattern means that despite the abundant information available in the internet, not all of the information provided by political parties reach the millennials.

\section{8 responses}

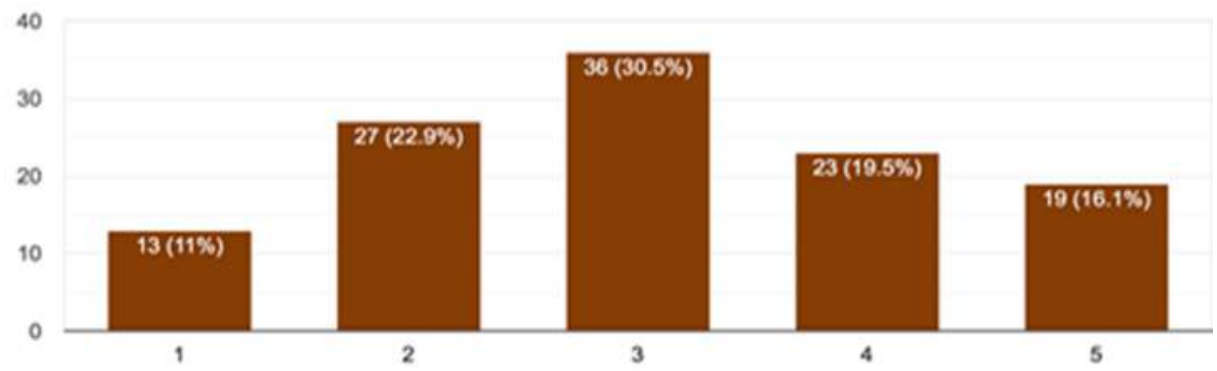

Figure 7. Understanding the vision, mission and views of political parties. 
The above chart demonstrates that the millennials know and understand the vision, mission and views of the political parties who propose candidates (presidents and members of parliament). It is based on this information that voters will give their vote. By having the knowledge about the political parties' views, it shows a degree of seriousness and interests by the millennials on the 2019 election.

\section{Discussion}

The findings of this study negate the taken for granted assumption and stereotypes circulating in the society about the millennial generation - that they are apathetic towards political processes. The three components of political attitudes, namely cognitive, affective and evaluative, demonstrated by the millennials show their positive interests. The cognitive aspect concerns with their understanding on the political processes of the election. The affective aspect deals with the excitement and general feeling over the experience of voting. The evaluative aspect refers to their general analysis and assessment on the politicians and parties involved in the election. In general, the study reveals that the millennial generation is not an apathetic generation towards social-political condition. Along with high connectives to the Internet, they are the most updated generation and thus having the most actual information [8]. In a comment received through the survey, one of the respondents realize that they use their votes because " 1 vote means a lot for our country" [1 suara sangat berpengaruh untuk negeri kita"]. Even, some scholars relate the awareness of using the vote with identities as millennials by saying that "34 percent of voters belong to the millennials, and that's me!" [ "34\% suara pemilu nanti adalah milik milenial, dan itu saya"]. This anecdote confirms Leyden's [9] opinion that the millennials are progressive. It is therefore too naïve that to ignore this segment of voters, moreover when the stereotypes have taken us all. The millennials should be understood and considered as important political actor that can use interactive media to actively create social changes. Therefore, what can be done to attract and involve them with new media's relevant to their lives.

\section{Conclusion}

The millennial generation, according to this study, demonstrates a positive perception towards the 2019 general election. This negates the circulating stereotypes attached to the millennials that they are indifferent to the social-political process. More importantly, their awareness is supported by the most updated information about the election due to high connectives with the Internet.

\section{References}

[1] S. Azwar, Sikap Manusia, Teori dan Pengukurannya. Yogyakarta: Pustaka Pelajar, 2015.

[2] A. Ahmadi, Psikologi Sosial. Jakarta: Rineka Cipta, 2009.

[3] S. Sastroatmodjo, Perilaku Politik. Semarang: IKIP Semarang Press, 1995.

[4] Khoiruddin, Partai Politik dan Agenda Demokrasi. Yogyakarta: Pustaka Pelajar, 2004. 
[5] M. Rush and P. Althoff, Pengantar Sosiologi Politik. Jakarta: Raja Grafindo Persada, 2003.

[6] G. Almond and S. Verba, Budaya Politik. Jakarta: Bina Aksara, 1990.

[7] N. Howe and w Strauss, Millennials Rising: the next great generation. New York: Vintage Books, 2000.

[8] M. Sandfort, "Whassup? A Glimpse into the Attitudes and Beliefs of the Millennial Generation,” J. Coll. Character, vol. 3, no. 3, 2002.

[9] P. Leyden, R. Teixeira, and E. Greenberg, The Progressive Politics of the Millennial Generation. Washington DC: New Politics Institute, 2007. 